\begin{tabular}{|c|c|c|}
\hline institute & $\begin{array}{l}\text { CARADDE: Jurnal Pengabdian Kepada Masyarakat } \\
\text { https://journal.ilininstitute.com/index.php/caradde } \\
\text { Volume 2 | Nomor 2 | Februari | 2020 } \\
\text { e-ISSN: } 2621-7910 \text { dan p-ISSN: 2621-7961 } \\
\text { DOI: https://doi.org/10.31960/caradde.v2i1.264 }\end{array}$ & $\begin{array}{l}\text { IIIN } \\
\text { EARAgDE }\end{array}$ \\
\hline
\end{tabular}

\title{
Penyuluhan Pendidikan Kesehatan Reproduksi Dan Bahaya Pornografi Untuk Anggota Palang Merah Remaja Tingkat Wira disalah satu SMA Kota Cirebon
}

\section{Dede Trie Kurniawan ${ }^{1}$, Sri Maryanti ${ }^{2}$}

$\begin{array}{ll}\text { Keywords : } & \text { Abstrak. } \\ \text { Palang Merah Remaja } & \text { Tujuan umum penyuluhan mengenai kesehatan reproduksi } \\ \text { Kesehatan Reprodusi Remaja } & \text { dan bahaya poronogarfi adalah memeberikan pendidikan } \\ \text { Bahaya Pornografi } & \text { kesehatan untuk remaja anggota ekstrakurikuler PMR agar } \\ & \text { dapat mengetahui dampak dari poronografi, mengetahui cara } \\ \text { Corespondensi Author } & \text { pencegahan pornografi di kalangan remaja dan memiliki } \\ \text { FKIP Universitas Swadaya Gunung Jati } & \text { wawasan serta pengetahuan tentang pola hidup sehat untuk } \\ \text { Cirebon }{ }^{1} & \text { kesehatan reproduksi mereka. Melalui kegiatan penyuluhan ini } \\ \text { Pendidikan Biologi Fakultas Tarbiyah } & \text { diharapkan dapat menjadi wadah pengalaman ilmu dan } \\ \text { dan Keguruan UIN Sunan Gunung } & \text { pembelajaran dari bidang kepakaran dosen yang dimiliki. } \\ \text { Djati Bandung }{ }^{2} & \text { Kegiatan Penyuluhan kesehatan reproduksi dan bahaya } \\ \text { Jl. AH. Nasuition No.105 } & \text { pornogarfi bagi remaja melalui ektrakurikuler PMR tingkat } \\ \text { Cipadung, Cibiru, Kota Bandung } & \text { wira ini bisa menjadi sebuah solusi yang dapat ditempuh } \\ \text { Jawa Barat, Indonesia } & \text { sebagai upaya pencegahan meluasnya dampak bencana } \\ \text { Coresponden@ Email: } & \text { pornografi pada remaja. Secara Garis besar Pelaksanaakan } \\ \text { Sri.maryanti@uinsgd.ac.id } & \text { kegiatan penyuluhan dapat dikategorikan sukses dan berjalan } \\ & \text { dengan baik. Hal ini dapat ditunjukan dengan sebagian besar } \\ \text { History Artikel } & \text { pemberian respon dari peserta yang mengungkapkan bahwa } \\ \text { Received: 09-Juli-2019; } & \text { kegiatan ini sangat baik karena dapat memberikan manfaat } \\ \text { Reviewed: 10-Oktober-2019; } & \text { dan memperluas wawasan mereka selaku anggota PMR } \\ \text { Accepted: 30-oktober-2019; } & \text { tingkat wira mengenai kesehatan reproduksi remaja dan } \\ \text { Avalaible Online: 04-November 2019; } & \text { bahaya pornogarfi bagi otak remaja } \\ \text { Published: 04-Februari-2020 } & \end{array}$

(c) (1) This work is licensed under a Creative Commons Attribution

4.0 International License

\section{PENDAHULUAN}

Indonesia kini dalam status darurat bahaya pornografi. Dampak pornografi yang semakin menghawatirkan ini tidak bisa didiamkan. Kasus yuyun seorang siswa smp yang menjadi korban pemerkosaan 14 pria remaja di bengkulu akibat pengaruh alkohol dan poronografi adalah menjadi sebuah tamparan keras buat dunia pendidikan indonesia di hari jadinya. Dari data Google Tren, diketahui bahwa pada tahun 2015 Indonesia berada pada peringkat teratas pengakses kata kunci 'sex' dan 'phone' di mesin-mesin pencari (seacrch engine) internet Yang memprihatinkan, ketika diteliti lebih mendalam ternyata pengakses materi pornografi terbesar adalah remaja (APJJI, 2014). Hal Ini dikuatkan dengan Temuan Yayasan Kita dan Buah Hati (YKBH), Jakarta, terutama terhadap siswa kelas IV hingga VI SD, sepanjang tahun 2008 sampai awal 2010 di Jabodetabek. Sebanyak 67 persen dari mereka telah melihat atau mengakses pornografi, dengan 37 persen di antaranya mengakses dari rumah sendiri. 
Dosen sebagai pelaku di bidang pendidikan tidak boleh diam terhadap ancaman kerusakan generasi penerus bangsa. Dosen Berkewejiban untuk untuk memenuhi tridharma perguruan tinggi, yaitu pendidikan, penelitian dan pendidikan. Sesuai dengan kapasistas keahlianya dosen yang dipandang sebagai tenaga ahli, perlu memberikan wawasan dan pengetahuannya kepada generasi muda yang masih dalam kategori remaja disekolah mengenai kesehatan reproduksi dan bahaya dari dampak poronografi bagi kehidupan remaja.

Remaja era informasi saat ini, sedang diserang dengan mudahnya akses untuk menelusuri poronografi. kemungkinan besar anak-anak Indonesia bisa terjangkit virus ketagihan pornografi. Apalagi, saat para anak mendapatkan fasilitas lebih dari orang tua mereka, seperti TV berbayar, gadget, wifi dan sebagainya. Kemudian ditambah lagi dengan kurangnya pengawasan orang tua yang sebagian besar jadwalnya sangat padat. Sangat berbahaya bila mereka mencari tau sendiri atas jawaban - jawaban penasaran mengenai hal yang selama ini dianggap tabu. Sangat mungkin rasa ingin tahu mereka akan menjerumuskan mereka. Maka dengan penyuluhan dengan mendatangkan ahli diharapkan dapat memberikan pemahaman dan wawasan untuk bisa menjaga diri dari dampak pornogarfi bagi remaja.

Masa remaja merupakan bagian dari proses tumbuh kembang, yaitu masaperalihan dari anak menuju dewasa. Pada tahap ini, anak mengalami percepatanpertumbuhan, perubahan-perubahan baik fisik maupun psikologis. Oleh karenanya, remaja sangat rentan sekali mengalami masalah psikososial, yakni masalah psikis atau kejiwaan yang timbul sebagai akibat terjadinya perubahan sosial.

Pendidikan seks sejatinya bukan hanya mengantisipasi anak agar tidak menjadi korban kejahatan seksual tetapi juga mencegah anak menjadi pelaku dari kejahatan tersebut. Selain itu cakupan pendidikan seksual sangat luas, tidak terbatas memberikan pengertian terhadap anak-anak dan remaja tentang masalah seks, bahaya serta manfaat dari seks itu sendiri. Namun pendidikan seksual pada hakikatnya lebih dari sekedar memberikan pengertian tetapi juga berusaha menanamkan moralitas seksual dalam diri anak-anak.
Menanamkan moralitas seksual kepada anak bisa dilakukan dengan langkah yang mudah dan sederhana, karena pendidikan kesehatan reproduksi pada anak bisa dimulai dari lingkungan terdekat anak yaitu keluarga. Contoh yang bisa dilakukan adalah mengajarkan kepada anak tentang cara menjaga kebersihan organ reproduksi, cara perawatan organ reproduksi yang baik dan benar dan mengajarkan kepada anak gaya hidup yang sehat.

Di Era Globalisasi ini, masih banyak remaja yang kurang memperhatikan kesehatan dan kebersihan alat reproduksi mereka, bahkan para remaja sekarang jauh lebih mementingkan penampilan luar (wajah dan cara berpakaian) daripada kesehatan alat reproduksi mereka yang dapat menentukan masa depan mereka terutama setelah menikah.

Para remaja masih belum tahu bagaimana cara membersihkan alat reproduksi secara tepat dan masih banyak yang belum tahu mengenai bahaya/ penyakit-penyakit yang muncul berkaitan dengan alat reproduksi mereka masing-masing. Disini diharapkan agar para remaja lebih meningkatkan pengetahuan mereka mengenai alat reproduksi mereka, guna menciptakan remaja yang memiliki imunitas yang tinggi dan berkualitas. Dari latar belakang yang telah dipaparkan, maka perlu dilakukan kegiatan penyuluhan mengenai kesehatan reproduksi dan bahaya pornografi bagi remaja dengan menggandeng ekstrakurikuler palang merah remaja (PMR) sebagai partner kegiatan. PMR ini untuk tingkat SMA yang dikenal dengan PMR Wira berfungsi sebagai peer educator yaitu pendidik sebaya keterampilan hidup sehat. Melalui anggota PMR inilah diharapkan hasil penyuluhan dapat disebarkan ke teman teman disekolahnya.

\section{METODE}

Kegiatan Penyuluhan kesehatan reproduksi dan bahaya pornogarfi bagi remaja melalui ektrakurikuler PMR tingkat wira ini bisa menjadi sebuah solusi yang dapat ditempuh sebagai upaya pencegahan meluasnya dampak bencana pornografi pada remaja.

Telah dilaksanakan kegiatan penyuluhan kesehatan reproduksi dan 
bahaya pornogarfi bagi anggota PMR di salah satu SMA Kota Cirebon dilaksanakan dengan acara tatap muka dan disuksi. Secara garis besar kegiatan berjalan dengan baik dan lacar. Pertemuan tatap muka dengan metode ceramah dan demonstrasi menggunakan video melalu media laptop dan infokus yang difasilitasi oleh sekolah. Kegiatan ini dilaksanakan sehari yaitu pada hari sabtu tanggal 30 juli 2016 dari pukul 13.00 - 14.30 WIB. Peserta kegiatan berjumlah 36 orang yang merupakan anggota PMR kelas X,XI dan XII SMA negeri 4 kota Cirebon dan Korps Sukarela PMI Unswagati Cirebon. Lokasi Penyelenggaraan penyuluhan ini dilaksanakan di salah satu kelas SMA Negeri 4 Kota Cirebon. Adapun yang menjadi pemateri pada pokok bahasan bahaya pornografi bagi otak remaja adalah Dede Trie Kurniawan, S.Si., M.Pd yang merupakan dosen FKIP Unswagati Cirebon ; sedangkan untuk materi kesehatan reproduksi bagi remaja adalah Sri Maryanti, S.Si., M.Pd yang merupakan Dosen Pendidikan Biologi Fakultas tarbiyah dan keguruan UIN Sunan Gunung Djati Bandung.

Pelaksanaan kegiatan

penyuluhan kesehatan reproduksi dan bahaya pornogarfi bagi anggota PMR di salah satu SMA Kota Cirebon ini dilakukan 2 (dua) orang tim pemateri dengan pokok bahsan yang disampaikan mengenai : Bahaya Pornogarfi bagi Otak Remaja, Kesehatan Reproduksi Remaja, Diskusi tanya jawab, Pengisian Lembar Evaluasi pelaksanaan kegiatan, dan Ramah - tamah dan foto bersama. Semua Kegiatan dapat terlaksanan kegiatan baik dan lancar berkat dukungan dan bantuan semua pihak baik sekolah maupun kampus.
Kegiatan yang diawali dengan perkenalan pemateri dan penyampaian maksud dan tujuan diselenggarakannya kegiatan penyuluhan ini untuk anggota PMR Tinglat wira di SMA negeri 4 Kota Cirebon. Dari Kegiatan penyuluhan ini, dapat diketahui bahwa pada umumnya peserta antusias dan baru mengetahui mengenai kesehatan reproduksi remaja dan bahaya pornografi bagi otak mereka. Acara kemudian dilanjutkan dengan sesi tanya jawab. Secara Garis Besar Inti pertanyaan para peserta adalah : Penjelasan kebenaran Ilmiah mengenai mitos saat wanita sedang menstruasi, Permaslahan psikologi remaja, dan perubahan fisik yang terjadi pada usia remaja, Usaha yang dapat dilakukan agar dapat terhindar dari bahaya pornogarfi, Usaha yang perlu dilakukan oleh perempuan agar "terjaga" dengan baik di pergaulannya, dan Diskusi Tindak Lanjut Kegiatan Tindak Lanjut kegiatan Penyluhan di sekolah.

Tujuan monitoring dan evaluasi pelaksanaan penyuluhan ini, antara lain: (1) Untuk menjamin terlaksananya penyuluhan sesuai dengan target dan rencana yang telah ditetapkan; (2) Agar ada umpan balik terhadap pelaksanaan penyuluhan; (3) Untuk membantu pemangku kepentingan belajar lebih banyak mengenai penyuluhan kesehatan reproduksi dan bahaya pornografi; (4) Agar penyuluhan mampu mempertanggungjawabkan penggunaan dana.

Instrumen yang akan digunakan untuk mengumpulkan data untuk monitoring dan evaluasi, yaitu: (1) Kuesioner dirancang untuk mengungkap reaksi peserta terhadap pelaksanaan penyluhan; (2) Pedoman wawancara untuk pembina PMR dan anggota PMR; (3) Dokumentasi berupa foto dan video pelaksanaan kegiatan penyuluhan. 
Caradde: Jurnal Pengabdian Kepada Masyarakat

Vol 2 No 2, Februari 2020

Tabel 1. Rencana Moitoring dan Evaluasi

\begin{tabular}{|c|c|c|c|}
\hline $\begin{array}{c}\text { Level } \\
\text { Evaluasi }\end{array}$ & Jenis data & $\begin{array}{c}\text { Sumber } \\
\text { data }\end{array}$ & Intrumen \\
\hline \multirow[t]{2}{*}{$\begin{array}{l}\text { Reaksi } \\
\text { partisipan }\end{array}$} & Pemateri & Peserta & $\begin{array}{l}\text { - Kuesioner } \\
\text { - Pedoman } \\
\text { wawancara }\end{array}$ \\
\hline & $\begin{array}{l}\text { Pelaksanaa } \\
\text { n kegiatan }\end{array}$ & Peserta & $\begin{array}{l}\text { - Kuesioner } \\
\text { - Pedoman } \\
\text { wawancara }\end{array}$ \\
\hline $\begin{array}{l}\text { Dukungan } \\
\text { organisasi } \\
\text { dan belajar }\end{array}$ & $\begin{array}{l}\text { Pembina } \\
\text { PMR }\end{array}$ & Peserta & Kuesioner \\
\hline $\begin{array}{l}\text { Penggunaan } \\
\text { pengetahuan } \\
\text { dan } \\
\text { keterampila } \\
\mathrm{n} \text { baru }\end{array}$ & $\begin{array}{l}\text { Anggota } \\
\text { PMR }\end{array}$ & $\begin{array}{c}\text { Pembin } \\
\text { a PMR } \\
\text { dan } \\
\text { Guru } \\
\text { Biologi }\end{array}$ & $\begin{array}{l}\text { lembar } \\
\text { observasi }\end{array}$ \\
\hline
\end{tabular}

\section{HASIL DAN PEMBAHASAN}

Kegiatan Penyuluhan kesehatan reproduksi dan bahaya pornogarfi bagi anggota PMR di salah satu SMA Kota Cirebon dilaksanakan dengan acara tatap muka dan disuksi. Secara garis besar kegiatan berjalan dengan baik dan lacar. Pertemuan tatap muka dengan metode ceramah dan demonstrasi menggunakan video melalu media laptop dan infokus yang difasilitasi oleh sekolah. Kegiatan ini dilaksanakan sehari yaitu pada hari sabtu tanggal 30 juli 2016 dari pukul 13.00 - 14.30 WIB. Peserta kegiatan berjumlah 36 orang yang merupakan anggota PMR kelas X,XI dan XII SMA negeri 4 kota Cirebon dan Korps Sukarela PMI Unswagati Cirebon. Lokasi Penyelenggaraan penyuluhan ini dilaksanakan di salah satu kelas SMA Negeri 4 Kota Cirebon.

Pelaksanaan kegiatan penyuluhan kesehatan reproduksi dan bahaya pornogarfi bagi anggota PMR di salah satu SMA Kota Cirebon ini dilakukan 2 (dua) orang tim pengabdi dengan pokok bahsan yang disampaikan mengenai: (1) Bahaya Pornogarfi bagi Otak Remaja; (2) Kesehatan Reproduksi Remaja; (3) Diskusi tanya jawab; (4) Pengisian Lembar Evaluasi pelaksanaan kegiatan; (5) Ramah - tamah dan foto bersama

Semua Kegiatan dapat terlaksanan kegiatan baik dan lancar berkat dukungan dan bantuan semua pihak baik sekolah maupun kampus. Kegiatan yang diawali dengan perkenalan pemateri dan penyampaian maksud dan tujuan diselenggarakannya kegiatan penyuluhan ini untuk anggota PMR Tinglat wira di SMA negeri 4 Kota Cirebon. Dari Kegiatan penyuluhan ini, dapat diketahui bahwa pada umumnya peserta antusias dan baru mengetahui mengenai kesehatan reproduksi remaja dan bahaya pornografi bagi otak mereka. Acara kemudian dilanjutkan dengan sesi tanya jawab. Secara Garis Besar Inti pertanyaan para peserta adalah Penjelasan kebenaran Ilmiah mengenai mitos saat wanita sedang menstruasi. Permaslahan psikologi remaja, dan perubahan fisik yang terjadi pada usia remaja. Usaha yang dapat dilakukan agar dapat terhindar dari bahaya pornogarfi. Usaha yang perlu dilakukan oleh perempuan agar "terjaga" dengan baik di pergaulannya. Diskusi Tindak Lanjut Kegiatan Tindak Lanjut kegiatan Penyluhan.

Adapaun Secara Garis Besar Respon peserta terhadap kegiatan penyuluhan kesehatan reproduksi dan bahaya pornogarfi bagi anggota PMR di salah satu SMA Kota Cirebon dapat dilihat pada gambar 2 .

Hasil kegiatan Penyuluhan kegiatan penyuluhan kesehatan reproduksi dan bahaya pornogarfi bagi anggota PMR di salah satu SMA Kota Cirebon secara garis besar mencangkup beberapa komponen sebagai berikut Keberhasilan target jumlah peserta yang mengikuti kegiatan. Ketercapaian Tujuan kegiatan penyuluhan. Ketercapaian target meteri yang telah direncanakan dan disampaikan. Kemampuan peserta dalam memhami memgenai kesehatan reproduksi dan bahaya pornografi

Target Peserta seperti direncanakan sebelumnya adalah paling tidak 30 peserta anggota PMR tingkat wira dan KSR PMI yang ada dicirebon. Dalam pelaksanaannya kegiatan ini diikuti oleh 30 peserta anggota PMR tingkat wira SMA Negeri 4 kota cirebon dan 6 anggota KSR PMI Unswagati cirebon. Dengan demikian dapat dikatakan bahwa kegaiatan penyuluhan melebihi target yang direncanakan. Dengan 36 Peserta ini meunjukan bahwa kegiatan penyuluhan kesehatan reproduksi dan bahaya pornogarfi bagi anggota PMR di salah satu SMA Kota Cirebon dilihat dari jumlah peserta yang mengikuti dapat dikatakan berhasil/sukses. 

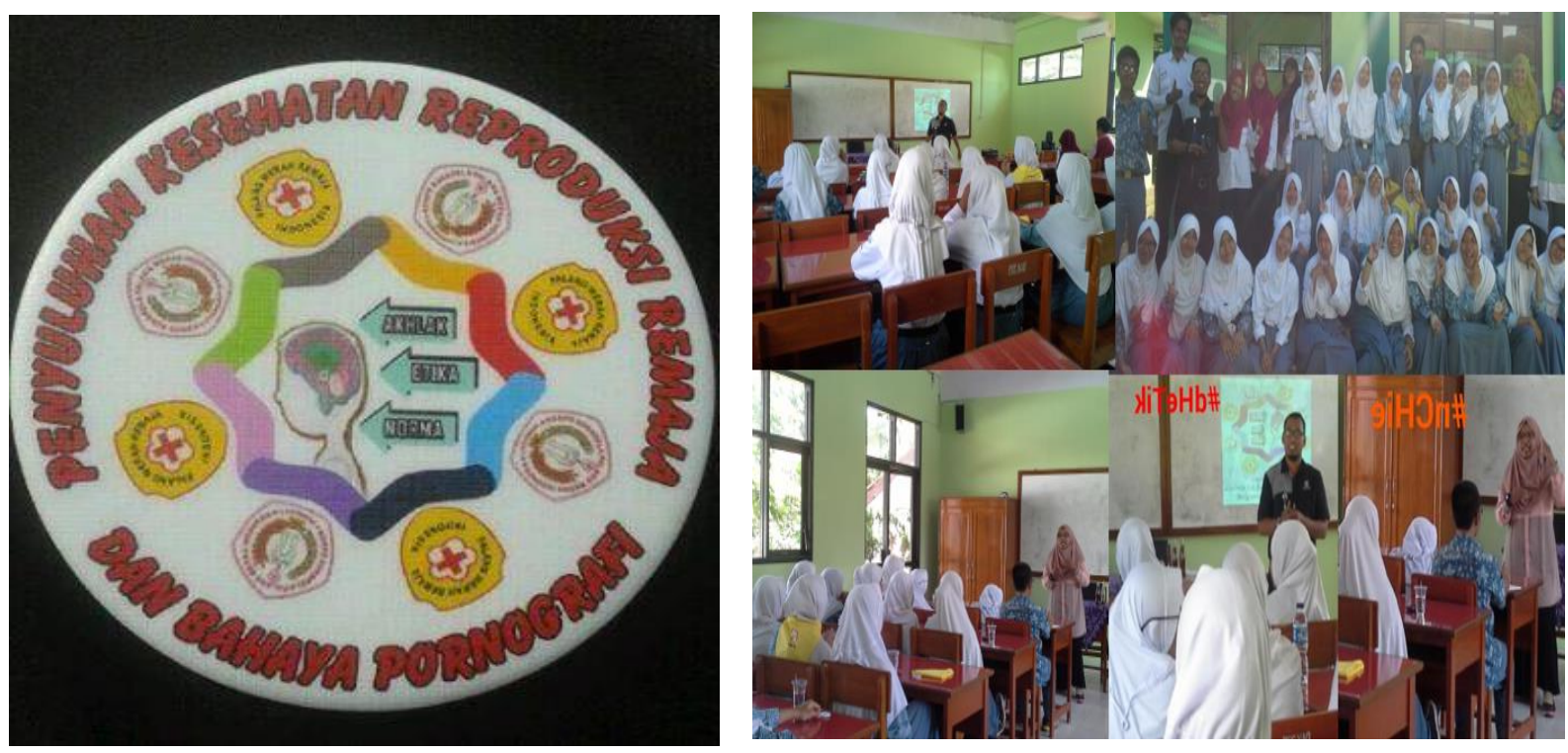

Gambar 1: Tim Memberikan Materi dalam Penyuluhan Kesehatan Repreoduksi dan Bahaya Pornografi bagi Anggota PMR Tingkat Wira disalah satu SMA Kota Cirebon

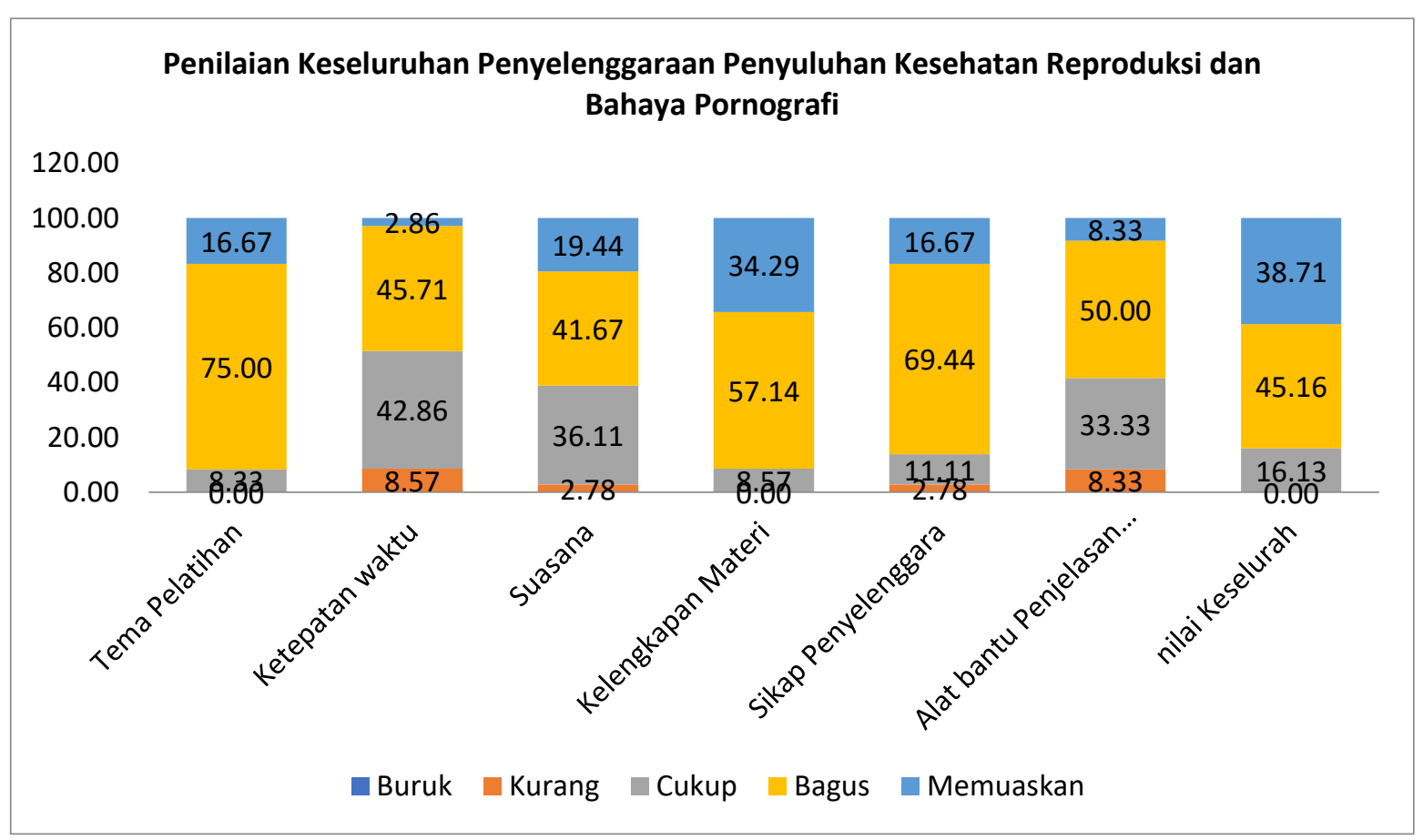

Gambar 2. Respon Peserta terhadap Keseluruhan Kegiatan Penyuluhan kesehatan reproduksi dan bahaya pornogarfi bagi anggota PMR di salah satu SMA Kota Cirebon 


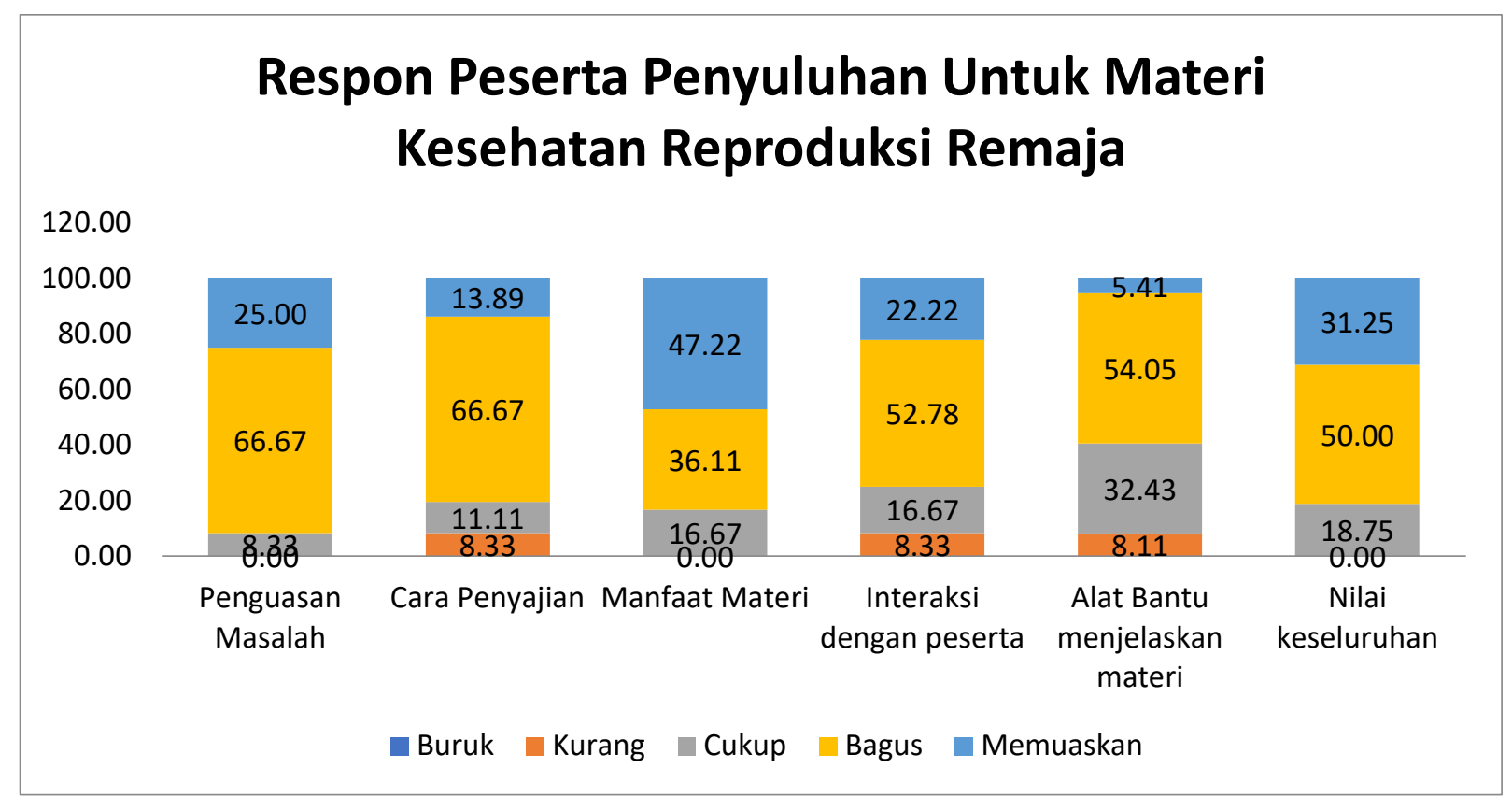

Gambar 3. Respon Peserta Terhadap Materi Kesehatan Reproduksi Remaja

\section{Respon Peserta Penyuluhan Untuk Materi Bahaya Pornografi Untuk Otak Remaja}

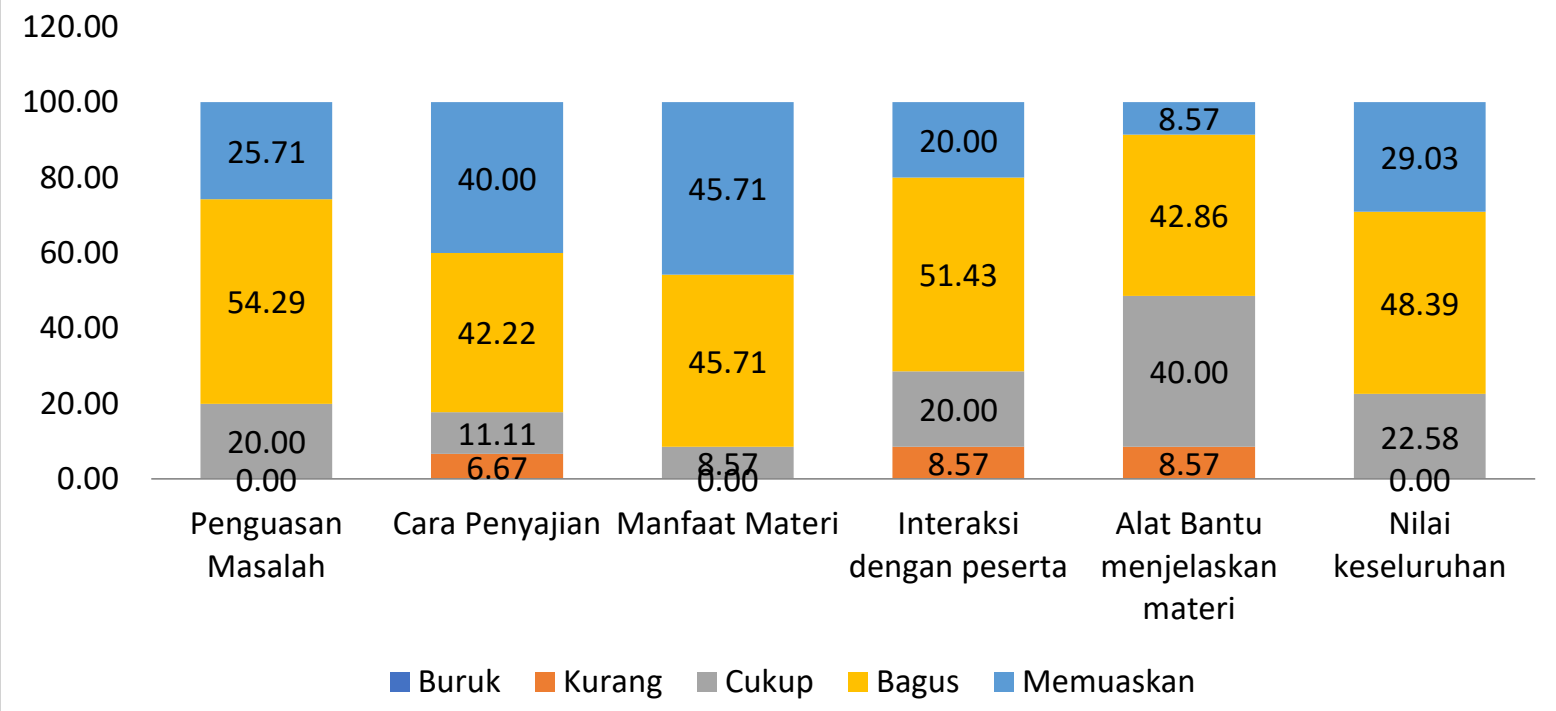

Gambar 4. Respon Peserta Terhadap Materi Bahaya Pornogarfi bagi otak remaja

Ketercapaian tujuan kegiatan penyuluhan secara umum sudah baik, hal ini dapat dilihat dari angket hasil respon peserta terhadap kegiatan penyuluhan secara keseluruhan atau tiap materi. Sebanyak 45.16 $\%$ peserta mengungkapkan kegiatan penyluhan ini bagus,dan $38.71 \%$ mengungkapkan bahwa kegiatan penyuluhan ini memuaskan mereka.

Ketercapaian target materi yang disampaikan dalam kegiatan penyuluhan kesehatan reproduksi dan bahaya pornogarfi bagi anggota PMR di salah satu SMA Kota Cirebon secara umum sudah sangat baik. hal 
Dede Trie Kurniawan, Sri Maryanti. Penyuluhan Pendidikan Kesehatan Reproduksi

ini dapat dilihat dari angket hasil respon peserta terhadap kegiatan penyuluhan secara keseluruhan atau tiap materi. Sebanyak 57.14 $\%$ peserta mengungkapkan kegiatan penyluhan ini bagus untuk kelengkapan materi ,dan $38.71 \%$ mengungkapkan bahwa kegiatan penyuluhan ini memuaskan mereka dari segi kelengkapan materi yang dipaparkan.

$$
\text { Kemampuan peserta dalam }
$$

memahami mengenai kesehatan reproduksi dan bahaya pornogarfi dapat dikategorikan baik. Hal ini dapat terlihat dari diskusi mengenai anatomi organ reproduksi dan bagaiamna cara menjaga kesehatannya yang dipandu oleh pemateri. Hal ini juga terungkap pada disuksi tanya jawab peserta yang secara umum mereka memahami mengenai organ reproduksi mereka dengan baik dan benar.

Secara Keseluruhan kegiatan penyluhan ini dapat dikategorikan berhasil dengan melihat pencapaian - pencapaian yang telah didapatkan. Secara garis besar peserta dapat mengambil banyak manfaat dari kegiatan penyluhan ini. Hal ini terungkap dari komentar respon yang diungkapkan melalui angket yang pada umumnya komentarnya berisi kegiatan penyuluhan ini memeberikan manfaat bagi mereka.

\section{SIMPULAN DAN SARAN}

Program penyuluhan kesehatan reproduksi dan bahaya pornogarfi untuk anggota PMR tingkat wira disalah satu sekolah SMA kota cirebon dapat diselenggarakan dengan baik dan berjalan dengan lancar sesuai dengan rencana kegiatan yang telah disusun. meskipun adanya keterbatasan waktu diskusi dan perencanaan tindak lanjut yang tidak banyak terungkap dari kegiatan penyuluhan ini.

Berdasarkan evaluasi yang telah dilakukan dapat diujukan beberapa saran sebagai berikut Waktu Pelaksanaan penyuluhan yang sebaiknya masuk dalam jam pelajaran agar kegiatan ini dapat masuk dalam kegiatan intrakurikuler jam pelajaran, sehingga bisa lebih banyak diikuti oleh siswa yang bukan hanya anggota PMR Dan Perlu pendampingan dan pembuatan program kader teman sebaya untuk kesehatan reproduksi dan bahaya pornografi bagi remaja, sehingga para kader ini bisa menyebarluaskan pemahaman mereka tentang kesehatan reproduksi remaja dan bahaya pronografi ke teman sebaya mereka dalam satu sekolah atau lain sekolah.

1. Perlu adanya kegiatan lanjutan berupa penyuluhan lanjutan secara periodik dengan pemateri dokter atau ahli psikologi yang memahami betul mengenai kesehatan reproduksi dan bahaya pornogarfi bagi diri remaja.

\section{DAFTAR RUJUKAN}

Anak-anak Indonesia juara satu pengakses situs porno. (2013, 14 November). Diunduh darihttp://www.merdeka.com/peristiw a/anak-anak-indonesia-juara-1pengakses-situsporno.html

APJII.(2014). Profil Pengguna Internet Indinesia 2014. Jakarta.

Ariyanti, Tia.2011. Pengaruh Peran Organisasi Palang merah remaja pada keprdibadian anggotanya. SMA Negeri 3 Batam

BKKBN. (2004). Anak Indonesia rentan pornografi . Diakses dari http:// hqweb01.bkkbn.go.id/article_detail.pi hp?aid=531.

Euis Supriati dan Sandra Fikawati. 2009. Efek Paparan Pornografi Pada Remaja SMP Negeri Kota Pontianak Tahun 2008. Makara, Sosial Humaniora, Vol. 13, No. 1, Juli 2009: 48-56.

Himpunan Psikilogi Indonesia. 2016. Psikologi dan Teknologi Informasi (seri pemikiran psikologi untuk bangsa 2).

Hutagalung, Inge. 2018. Sosialisasi dan pencegahan kecanduan pornografi di kalangan remaja keluarahan mapar, kecamatan taman sari, jakarta barat. Jurnal Abdi Moestopo. Vol.1.no.1pp14-18

Hutagalung, Inge. 2016. Disonansi Kognitif pada Perilaku Seks Pranikah, Jurnal Komunikasi Ikatan Sarjana Komunikasi Indonesia, Vol.1(2), 7180.

Lende, Y.B. (2015). Internet dan eksplorasi diri manusia. Kompasiana.com 
Caradde: Jurnal Pengabdian Kepada Masyarakat

Vol 2 No 2, Februari 2020

Murti, I.R. (2008). Hubungan antara frekuensi paparan pornografi melalui media massa dengan tingkat perilaku seksual pada siswa SMU Muhammadyah 3 tahun 2008. Fakultas Kesehatan Masyarakat, Universitas Indonesia.

Sari, Katrin Pornomo.2010. Pengetahuan Kesehatan Reproduksi Ditinjau dari persepsi kualitas Komunikasi orang tua dan remaja. UIN Yogyakarta

Palfey, J. \& Gasser, U.(2008).Born Digital. Understanding the first generation of digital natives. Newyork: Basic book

Pertiwi Karika Ratna,Kesehatan reproduksi remaja dan pemasalahannya. Jurusan Pendidikan Biologi FMIPA UNY.
Rahmawati, L. (2015). Waspada pornografi di sinetron, komik, game. http://www.antaranews.com/berita/505 269/waspadapornografi-di-sinetronkomik-game, diakses 20 Maret 2016.

Risman, E. (2015). Pornografi di rumah kita. Seminar Bahaya Pornografi .

Soetjiningsih. 2006. Remaja Usia 15-18 Tahun Banyak Lakukan Perilaku SeksualPranikah.http://www.ugm.ac.i $\mathrm{d} /$ index.php?page $=$ rilis\&artikel $=1659$. diakses tanggal 13 Juli 2010

Undang-Undang Republik Indonesia tentang Pornografi nomor 44 tahun 2008. 